\title{
SAUDI ARABIA AS A REGIONAL POWER AND AN ABSOLUTE MONARCHY UNDERGOING REFORMS. VISION 2030 - THE PERSPECTIVE OF THE END OF THE SECOND DECADE OF THE $21^{\text {ST }}$ CENTURY
}

Saudi Arabia in the two first decades of the $21^{\text {st }}$ century is undoubtedly one of the most important players on the Middle Eastern scene, but also a major player on the global scene. The Saudi state is the cradle of Islam and two most significant religious centres - Mecca and Medina - are situated in its territory. Modern Saudi Arabia was established in 1932 by Abd al-Aziz Ibn Abd Rahman al-Saud after almost a 30-year long campaign for the unification of the biggest part of the Arabian Peninsula. In accordance with the Basic Law of 1992, one of the male descendants of Ibn Saud has supreme authority in the Saudi monarchy, which remains essentially an absolute monarchy. Since January 2015 King Salman Ibn Abd al-Aziz Saud has been the head of state. At the end of the second decade of the $21^{\text {st }}$ century Saudi Arabia together with Brunei (Negara Brunei Darussalam) remain the only absolute monarchies in the world.

Therefore, it would seem that Saudi Arabia, as a regional power, is an internally stable state, which does not require radical reforms. However, nothing could be further from the truth. Saudi Arabia at the end of the second decade of the 21 st century is an internally destabilised state, suffering an economic crisis and requiring thoroughgoing political, economic and social reforms. It is a state which not only sponsors terrorism (Pratt, 2006: 1-15), but also faces acts of terrorism in its own territory. It is a state with an enormous gap between the authorities and the citizens. This gap was strongly manifested in the lack of Saudi society's acceptance of the decision made by the Saudi ruling elites in the early 1990s concerning the presence of American troops in their territory, as well as in the World Trade Center and Pentagon terrorist attacks on 11 September 2001, when it turned out that 15 of the 19 terrorists were the citizens of Saudi Arabia. Finally, Saudi Arabia is a state that politically and mentally remains a feudal monarchy, which is dominated by the absolute ruler and where no fundamental rights and civil liberties are guaranteed and women - in accordance with the sharia law - continue to play a secondary role in the Saudi society.

Interestingly, though, the negative image of the politically ossified Saudi Arabia which is propagated in the global media, has been recently increasingly recognised by the authorities in Riyadh. In order to add some warmth to the image of both the royal family and the whole state, and thus strengthen the position of Saudi Arabia 
on the regional and international scene and enhance bilateral relations - including relations with the United States - the authorities in Riyadh made a decision on carrying out a number of economic, political and social reforms, aimed at making Saudi Arabia a regional hegemon with a positive external image. Successive reforms have been implemented with variable effects for a few years and some of them are to be implemented within the medium-term or long-term framework (Vision 2030, National Transformation Plan or Fiscal Balance Plan).

The research objective of this paper is to analyse the determining factors which allow Saudi Arabia at the end of the second decade of the 21st century to hold the position of a great power and even a regional hegemon and to maintain it at least in the medium-term perspective. This paper also aims at an analysis of the potential effectiveness of the reforms which have been and are still being carried out by the authorities in Riyadh in order to create a new, modified image of the feudal monarchy - Saudi Arabia as an enlightened (but permanently absolute) monarchy undergoing reforms. The methods used in this paper include: content analysis, systemic analysis and comparative method. The hypothesis formed and verified in this paper is as follows: Saudi Arabia at the end of the second decade of the $21^{\text {st }}$ century is a regional power and an absolute monarchy undergoing reforms, which intends to build a new, positive and friendly image of the kingdom through reforms introduced in the economic, political and social spheres. The reforms undertaken in the Saudi state, however, actually take place only at the economic level, which results from the fact that they do not undermine the foundations of the sharia law and the doctrine of Wahhabism. In the political and social spheres the reforms are just a façade. Their task is to create apparent changes, which are formally in force, but in practice they cannot function due to fact that they are in contradiction with the radical Islam, which since the moment of proclamation of the state has been a stable pillar in the functioning of the kingdom and legitimates the ruling of the House of Saud.

\section{SAUDI ARABIA - ATTRIBUTES AND DETERMINING FACTORS OF A REGIONAL POWER}

Saudi Arabia is undoubtedly one of the key states in the Middle East, particularly in the subregion of the Persian Gulf. It is a regional power whose strength is based on attributes of geopolitical, economic, as well as cultural nature. The significance of Saudi Arabia both in the regional (Middle East) and global (international) relations is determined by a number of factors and circumstances, three of which are the most important. Firstly, Saudi Arabia is a state which is geostrategically situated in the heart of the Middle East. The location of the kingdom on the Persian Gulf - opposite the hostile Islamic Republic of Iran, as well as bordering Jordan, Iraq, Kuwait, Qatar, the United Arab Emirates, Oman and Yemen - some of which were or still are torn by civil war, and which have Shia minorities (Zaydi) in their territories - is strategic and requires the Saudi ruling elites to use appropriate instruments to pursue foreign policy, many of which involve hard power. Importantly, in the case of maintaining and strengthening the position of Saudi Arabia in the role of a regional hegemon, both 
objective and subjective factors have the decisive impact. The first group unquestionably includes the territorial and population factors. Saudi Arabia covers the area of 2,149,690 $\mathrm{km}^{2}$, which makes it the largest state in the Middle East (Iran comes second), and $13^{\text {th }}$ largest country by area in the world. As far as the population factor is concerned, it is to be assumed that Saudi Arabia has a population of 33.1 million (as at July 2018), which makes it rank number 41 in the list of countries by population in the world, but number 3 (behind Egypt and Iran) in the Middle East (Saudi Arabia, The World Factbook, 2019). Analysing the population factor, it is necessary to emphasize the religious and ethnic composition of the population of Saudi Arabia, since it is an Arab state (Arabs make up $90 \%$ of the total population, while Afro-Asians $10 \%$ - immigrants constitute as much as $37 \%$ of Saudi population), which is dominated by the radical Sunni Islam - the Wahhabism (Zepp Jr., 1992: 147.), and where the Saudi Sunnis compete for influence in the Middle East with the Iranian Shiites. From the perspective of the authorities in Riyadh, Tehran is the most serious competitor in the rivalry for the title of the hegemon in the region, which results from the fact that although Sunni Islam dominates (85-90\%) in the territory of Saudi Arabia, as much as $10-15 \%$ of the population is made up by the Shiites, who are mostly concentrated in the strategic part of the country - the Eastern Province - which is oil-rich and exposed to destabilising actions on the part of the authorities in Tehran. It was most clearly confirmed during the Arab Spring in 2011. As for the most significant subjective factors, which conveniently enable Saudi Arabia to use the hard power instruments, these are undoubtedly very close, strategic and even allied relations with the United States. The relations between the USA and Saudi Arabia are defined as symbiotic (Pustelnik, Lucic, 2009: 16), as for decades Saudi Arabia has been considered by successive American ruling classes as a guardian of the Persian Gulf subregion, keeping watch over the status quo in this part of the world. It is a state which, in the view of the American establishment, by weakening the Shia-dominated Iran, should guarantee stabilisation in the Middle East and play the role of a partner supporting the pro-American character of the territorially small monarchies of the Persian Gulf, which are rich in oil and natural gas (including Kuwait, Bahrain and Qatar) (Yateem, 2014: 97-100). It is worth noting that one of the factors affecting the strengthening of the American-Saudi alliance is the negative attitude of both the countries towards the Islamic Republic of Iran, which from their point of view poses a real threat to regional and international security. Tehran's regional ambitions remain in contradiction with Riyadh's policy, which is not manifested in a direct conflict, but is evident in the proxy wars waged by these states in the territories of Bahrain, Syria and Yemen (Ruys, Ferro, 2016: 61-98). The Saudi-Iranian rivalry for influence in the Persian Gulf subregion, and even in the whole Middle East, thus leads to a certain dichotomy of the region and to the creation of two competing centres. One dominant power is the Islamic Republic of Iran, striving to create an alliance of the Shia Crescent states (such as Iraq or Syria), whose allies include the Russian Federation and Turkey, with which it has been recently convergent in many areas of the Middle East policy. The other dominant power is Saudi Arabia, which is building a Sunni alliance among republics (such as Egypt) and regional monarchies (Kuwait, Qatar, Bahrain) and other Middle East states which see Iran in the framework of the policy of Shia expansion- 
ism, with the unambiguous and almost unconditional support it receives for its policy from the White House (Kaldor, 2014: 164-166).

Secondly, Saudi Arabia is a state which is rich in energy resources (the largest in the Middle East) - especially oil. Saudi Arabia ranks as the largest exporter of oil in the world (7.3 million barrels per day) and its oil reserves are the second largest in the world behind only Venezuela (266.2 billion barrels - as of 2018). Importantly, extraction of oil in Saudi Arabia is considerably cheaper than in Venezuela (Saudi Arabia, The World Factbook, 2019). Saudi Arabia also ranks as the second largest oil producer behind the United States (over 10 million barrels per day), which undoubtedly makes it a decision-maker on the global energy market ${ }^{1}$. Saudi Arabian Oil Company (Saudi Aramco), which was established in 1933, is the world's biggest oil producer and stateowned company which is engaged in oil exploration and production (Scwebel, 2010: 245-256). As the world's leading oil producer, Saudi Aramco accounts for around 10\% of the global oil supply. Most of the well-known Saudi oil fields are located in the Shiadominated Eastern Province (including the largest conventional oil field in the world - Ghawar), and the largest offshore oil field is situated in Safaniya in the Persian Gulf. ARAMCO has also discovered large reserves of natural gas and oil in the central part of Saudi Arabia (Prados, 2006).

Table 1

The 10 largest oil producers and share of total world oil production in 2019

\begin{tabular}{|l|c|c|}
\hline \multicolumn{1}{|c|}{ Country } & Million barrels per day & Share of world total \\
\hline United States & 19.51 & $\mathbf{1 9 \%}$ \\
\hline Saudi Arabia & 11.81 & $\mathbf{1 2 \%}$ \\
\hline Russia & 11.49 & $\mathbf{1 1 \%}$ \\
\hline Canada & 5.50 & $5 \%$ \\
\hline China & 4.89 & $5 \%$ \\
\hline Iraq & 4.74 & $5 \%$ \\
\hline United Arab Emirates & 4.01 & $4 \%$ \\
\hline Brazil & 3.67 & $4 \%$ \\
\hline Iran & 3.19 & $\mathbf{3 \%}$ \\
\hline Kuwait & 2.94 & $3 \%$ \\
\hline Total top 10 & 71.76 & $71 \%$ \\
\hline
\end{tabular}

Source: What countries are the top producers and consumers of oil?, US Energy Information Administration, https://www.eia.gov/tools/faqs/faq.php?id=709\&t=6 (27.10.2020).

${ }^{1}$ According to one of the American cables sent from Saudi Arabia in 2007 and revealed by Wikileaks in 2010, the estimated values concerning Saudi oil reserves may have been overstated. The author of the cable referred to the knowledge of Sadad al-Husseini, who for 12 years, until 2004, was the head of exploration and production in the Saudi state-owned oil company ARAMCO. Al Husseini claimed that the period of plateau in the total output would last approximately 15 years followed by decreasing output (just after 2020). The forecasts of the former head of ARAMCO were based on the documents showing objectives and orientations of the oil policy of Saudi Arabia. The policy assumed the production of 12.5 million barrels of oil per day until 2009. The author of a cable of 2009 informed that experts were convinced that the civil nuclear program was the only possibility for the kingdom to generate the sufficient amount of electricity to meet the demand from the domestic economy and the growing population and to ensure greater prosperity without exploration of large quantities of oil. In 2009 Saudi Arabia announced the plans to build two nuclear power plants. 
Thirdly, a significant attribute of the regional power of the Kingdom of Saudi Arabia, which constitutes the third of the above-mentioned determining factors, is the cultural and religious sphere, which comes down to the fact that this country is regarded as the cradle of Islam and the historical Hejaz is the holy land for Muslims. In the year 622 Saudi Arabia was the place of the Hijra - a journey of prophet Muhammad from Mecca to Medina, which ended the period of Jahiliyyah (the age of ignorance, before the advent of Islam). Saudi Arabia's rulers, although - unlike some other royal families in the Arab states - they are not immediately related to prophet Muhammad and the Saud family are descendants of a camel breeder who came from Oman, are perceived as the ones to protect Muslim tradition. It is the King of Saudi Arabia that has the official title of the Custodian of the Two Holy Mosques. Mecca, again, is a pilgrimage site for Muslims from all over the world, who visiting this place perform the rites of Hajj, which is one of the pillars of Islam. In 2018 alone Mecca was visited by about 2 million Muslims, while in the years 1993-2018 the number of pilgrims amounted to around 54 million. It should also be stressed that Saudi Arabia is a state where a radical version of Islam, Wahhabism, is the dominant religion. It is based on the teaching of the more restrictive Quranic school - Hanbalism. Of particular importance is the fact that, while by the 1990s the Wahhabis limited their activity to the area of Saudi Arabia, in the following decades one of their main goals was the expansion of Wahhabism at both the regional and global scale (Bellaigue, 2017: XXIII-XXIV).

To sum up, looking at the Kingdom of Saudi Arabia from the cultural and political perspective, it seems that Grzegorz Małachowski, who analysed the constitutional system of this state, was right to observe that "Saudi Arabia is characterised by an unusual combination of traditional Islamic doctrine, resulting from the previous isolation of Najd, with a modern and still developing positivist legal system" (Małachowski, 2011: 6).

\section{ECONOMIC REFORMS AND A VISION OF SOCIAL CHANGES IN THE KINGDOM OF SAUDI ARABIA}

Putting forward the thesis that Saudi Arabia at the end of the second decade of the $21^{\text {st }}$ century is a regional power undergoing political transformation from an absolute monarchy towards an enlightened monarchy, it should be noted that this change is based on the processes taking place in the economic sphere and to a certain extent also in the social sphere. The reforms which have been carried out since 2017 are supported by the Saudi heir to the throne, 34-year old Prince Mohammed Bin Salman, who declared that the main goal of the changes being introduced was to turn Saudi Arabia into a modernised and open state, with moderation as its method, where there is no place for extremism. The instruments to be used for the performance of tasks defined in this way include the long-term economic initiatives, new laws, partial capitalisation and privatisation, as well as actions designed to achieve equal rights for women and men.

Therefore, analysing the economic sphere which has been subjected to transformation, it should be stressed that Prince Mohammed Bin Salman is the leader of flagship initiatives, such as Vision 2030, National Transformation Plan or Fiscal Balance Plan, 
whose main objective is to lead to the diversification of sources of revenue through transformations in Saudi economy and the reduction of its dependency on exploration and export of oil, whose resources are limited. Saudi authorities promoting the development of investments and of the private sector have introduced taxes, reduced the surcharge on energy and undertaken numerous actions to improve the state of public finances, which at the end of the second decade of the $21^{\text {st }}$ century is bringing tangible effects.

Promoting the Vision 2030 initiative, Mohammed Bin Salman stressed that his goal was to make the changes taking place in Saudi Arabia a model project of achieving excellence in all areas. Defining the three pillars of the project, he stressed that the first of them is the position of Saudi Arabia as the heart of the Arab and Islamic worlds. The second pillar was the determination to become a global investment powerhouse, which was to be aided by stimulating Saudi economy, as well as the policy to diversify revenues. The third pillar was the unique strategic location of Saudi Arabia, in the hub connecting three continents - Asia, Europe and Africa. The geographic position between key global waterways was to make the kingdom a kind of epicentre of trade and the gateway to the world markets. Mohammed Bin Salman argued: "We are determined to reinforce and diversify the capabilities of our economy [...]. We will transform Aramco from an oil producing company into a global industrial conglomerate. We will transform the Public Investment Fund into the world's largest sovereign wealth fund. We will encourage our major corporations to expand across borders and take their rightful place in global markets. [...] we continue to give our army the best possible machinery and equipment [...].We will expand the variety of digital services to reduce delays and cut tedious bureaucracy. [...] Our ambition is for the long term. It goes beyond replenishing sources of income that have weakened or preserving what we have already achieved. We are determined to build a thriving country in which all citizens can fulfil their dreams, hopes and ambitions. Therefore, we will not rest until our nation is a leader in providing opportunities for all through education and training, and high quality services such as employment initiatives, health, housing, and entertainment. We commit ourselves to providing world-class government services which effectively and efficiently meet the needs of our citizens. Together we will continue building a better country, fulfilling our dream of prosperity [...]. We will not allow our country ever to be at the mercy of a commodity price volatility or external markets. We have all the means to achieve our dreams and ambitions. There are no excuses for us to stand still or move backwards. Our Vision is a strong, thriving, and stable Saudi Arabia that provides opportunity for all. Our Vision is a tolerant country with Islam as its constitution and moderation as its method" (King Salman Bin Abdulaziz Al Saud, (2019): 6-7).

The constructors of Vision 2030 and of other associated projects stressed that the status of Saudi Arabia due to the planned transformation will allow the state to play the leading role in the Arab and Islamic world. The investment capabilities, being the strength of the kingdom, have been considered as a platform for building a more diversified and balanced economy, and the geopolitical location was to constitute an integral factor boosting international trade with Saudi Arabia as a global hub connecting Africa, Asia and Europe. What is extremely important is the fact that Vision 2030 
itself presented the three interdependent motives it was based on: 1. a vibrant society; 2. a thriving economy; 3 . an ambitious nation. The first motive was necessary in order to achieve an image of the state which guarantees social prosperity. As it was emphasized, members of Saudi society should live in accordance with the Islamic principle of moderation, be proud of their national identity and cultural heritage, enjoy life in a beautiful environment, based on families and a welfare state. Consequently, another indispensable element which guaranteed social well-being was a thriving but diversified economy and an expanded service sector, which would create opportunities for citizens through the modernisation of the educational system, matching labour market needs and creating economic opportunities for the development of both small-scale enterprises and big corporations. Saudi economy should encourage the best workers from all over the world to come and work there. Therefore, the third motive is based on an effective and responsible government characterised by transparency (Vision 2030, 2019).

The vision of changes to take place until 2030, presented by Saudi authorities was comprehensive and specific. It posed the fundamental question: how to achieve such ambitious objectives? The basic tools for the implementation of Vision 2030 indicated by the authorities include thirteen different instruments (programs), which have been gradually implemented with tangible effects: "The Government Restructuring Program; The Strategic Directions Program; The Fiscal Balance Program; The Project Management Program; The Regulations Review Program; The Performance Measurement Program; The Saudi Aramco Strategic Transformation Program; The Public Investment Fund Restructuring Program; The Human Capital Program; The National Transformation Program; The Program For Strengthening Public Sector Governance; The Privatization Program; The Strategic Partnerships Program" (Vision 2030, 2019).

Interestingly, on account of the economic reforms planned from the second half of the second decade of the $21^{\text {st }}$ century, whose aim was to modernise the kingdom and to make Saudi economy independent from the exploration of energy resources, as early as in 2016 the authorities in Riyadh made an unprecedented decision on the issuance of 5\% of shares of Saudi Aramco and investing USD 5 billion in the renewable energy sources. This decision constituted in a way the foundation of Vision 2030. In accordance with the concept of the originator of this undertaking, Prince Mohammed bin Salman, it was announced in February 2017 that the initial public offering would be led by three banks: JP Morgan Chase, HSBC and Morgan Stanley, and the shares - as indicated by some speculation - were to be traded on one of the global stock exchanges in New York, London, Hong Kong or Toronto and on the stock exchange in Saudi Arabia - Tadawul - with its seat in Riyadh. It was then estimated that the stock-market debut of the company - the biggest in the history of stock exchange investments - may create benefits of up to USD 100 billion, and the value of Saudi Aramco itself was estimated at USD 2.5 trillion (at the same time the value of Apple was approximately USD 1 trillion). The decision on the possibility to purchase the shares created quite a stir among the global decision makers, to the extent that the authorities in Beijing decided to create a special fund which was to invest only in this company. The authorities in Riyadh finally decided to conduct the sale of shares in cooperation with Evercore Inc., Moelis \& Co., HSBC Holdings Plc, JPMorgan Chase \& Co. and Morgan Stanley. However, 
the issuance of shares of Saudi Aramco planned for the year 2018 did not take place due to problems with obtaining the company's capitalisation, but also because of the internal Saudi disputes as to the place of the listing of Saudi Aramco shares. In mid2018 it was said that the listing of Saudi Aramco shares would be postponed to 2019, and also that the shares would not necessarily be listed on global stock exchanges (especially in New York, which was especially opted for by Prince Mohammed bin Salman), but only on Tadawul in Riyadh (Jaffe, 2019). After over two years of cooperation with the banks, Saudi Aramco formally suspended their plans to issue shares in 2018 and made an alternative decision to purchase shares in the local chemical sector giant Saudi Basic Industries Corp. for the value of USD 69 billion. Interestingly, only at the beginning of July 2019, it was publicly announced (which was revealed by Bloomberg), that the work on the issuance of Saudi Aramco shares has been resumed. However, due to the permanent lack of agreement among members of the authorities in Riyadh as to the place of listing of the shares, as well as due to a decrease in the prices of oil and the increasing concern of the biggest investors as regards investing in the fossil fuel companies at a time of climate change, the listing of Saudi Aramco shares is not a certain undertaking and it is not known whether it will actually take place in the following years. Prince Mohammed Bin Salman remains one its biggest propagators and publicly insists that the listing of Saudi Aramco shares take place in 2020 or 2021 at the latest (Nair, Narayanan, Martin, 2019).

However, it is also worth mentioning that the authorities in Riyadh, acting within the framework of the project of the great transformation of the kingdom, diversify not only the oil sector, but also develop the solar and nuclear energy sectors. Plans for construction of 16 nuclear reactors which are to be built in the following two decades were developed as early as in 2011. The total cost of this investment is to amount to about USD 7 billion USD. According to the project, which is consistent with the Vision 2030 initiative, the first two reactors are to be constructed by 2021, and another two by 2030 . As the Saudi party argued, the purpose of their functioning is to meet $20 \%$ of the national demand for electrical energy. In 2016 the authorities of Saudi Arabia announced plans for the installation of 9.5 gigawatts of solar energy within the framework of the Vision 2030 and Social Change program (Vision 2030, 2019). In these circumstances the cooperation between Riyadh and Washington became an important element of such a strategy. Importantly, Saudi Arabia has been in discussion with the USA about the cooperation in the nuclear sphere, however, no official statements have been made concerning this issue. However, as early as in April 2010 a dialogue was initiated in the King Abdullah City for Nuclear and Renewable Energy in order to review the plans for development of nuclear energy production and its inland consumption. Even before that, on 16 May 2008 Saudi Arabia and the USA signed the Memorandum of Understanding on Civil Nuclear Energy Cooperation, where Riyadh signalled the intention to undertake work on uranium enrichment or nuclear reprocessing (Memorandum..., 2008). In 2010 Barack Obama's administration estimated that within the framework of bilateral cooperation the USA could allocate USD 8,000 for the International Military Education and Training (IMET) and USD 200,000 for the security-related program Nonproliferation, Anti-terrorism, Demining, and Related Programs (NADR). In 2011 American administration allocated respectively: USD 10,000 for IMET and USD 
360,000 for NADR (Blanchard, 2011). Specific actions in this area resulted in the creation of the Saudi National Atomic Energy Project (SNAEP). The Saudi party justified that the creation of SNAEP was determined by a rapid growth in demand for energy in the industrial and housing sectors and by the need to reduce the dependence on hydrocarbons and the use of oil. Riyadh's energy policy, in accordance with the Vision 2030 initiative, was thus based on various elements, including nuclear energy to meet the energy requirements of the kingdom - production of electricity, thermal energy and seawater desalination. SNAEP was based on four fundamental elements: a large nuclear power plant, a small module reactor, a nuclear fuel cycle and a regulator (Saudi National Atomic Energy Project SNAEP, 2019).

The National Plan for Science, Technology and Innovation 2010-2025 (The National Plan for Science, Technology and Innovation, NPSTI 2010-2025) also plays a major role in the technological modification of the kingdom. The plan, among other things, assumes creation of technology parks, research centres and new universities and campuses, as well as reaching the enrolment rate of 50\%, creating an accreditation committee and subjecting all higher education institutions to the accreditation process. In Saudi Arabia there are over 30 state universities, including the biggest university for women in the Arab world, Princess Nora Bint Abdulrahman University in Riyadh. In addition, there are about 600 colleges. Private education makes up about $5 \%$ of the market and is not of particular interest nor is it highly regarded. Importantly, however, four universities with the biggest potential have been chosen within the initiative to modernise and develop scientific resources: King Abdullah University of Science and Technology, King Fahd University of Petroleum \& Minerals, King Saud University and King Abdulaziz University. These institutions will obtain the biggest funds for self-development. King Abdullah University of Science and Technology is an excellent example of the Saudis' changing mentality. The university is one of the best equipped higher education institutions in the world and its students also include women, who are not obliged to cover their faces and bodies (Al.-Rushaid, 2010: 7-12).

\section{THE MOST IMPORTANT CHANGES IN SOCIAL AND MORAL SPHERES}

What is important is the fact that economic initiatives aimed at transformation and modernisation of the Kingdom of Saudi Arabia are accompanied by very important changes in the social sphere - as regards the issue of women empowerment, as well as the opening up of the country to the world by creating an impression that Saudi Arabia is a friendly state which is opening to tourists and which is characterised by religious tolerance. Referring to particular actions of the state in this area, it should be emphasized, however, that, although the changes are real on the economic level, they are just a façade in the social sphere. Their introduction is necessary for building a positive image of the state, but the actual introduction (implementation through raising social awareness, civil liberties and building at least a substitute for a civil society) is limited due to the fact that it is in contradiction with the fundamentals of the radical Islam (Wahhabism), which for ages has constituted the basis for the Saudi power and has legitimated the ruling of the House of Saud. 
Therefore, analysing the social transformation taking place at the end of the second decade of the $21^{\text {st }}$ century in Saudi Arabia, the political sphere and the issue of the political participation of women in the kingdom should be particularly considered. It should be stressed that on 12 December 2015 women took part in the local elections for the first time. In accordance with the decision of the then ruling King Abullah, amid the protests and demands of the Arab Spring, women were granted both active and passive voting rights, and the king himself appointed 30 Saudi women for his Consultative Council (Shura), which comprises 150 people. In the elections to the 284 municipal councils, which took place in Saudi Arabia only for the third time, there were about 6 thousand male candidates and almost one thousand female candidates. However, out of all the persons entitled to vote, there were 1 million 300 thousand registered male voters and 10 times fewer women registered to vote (out of 4.5 million women entitled to vote only 130 thousand registered themselves). However, as Saudi activists stressed, the numbers were not so much of significance in this particular case, as the very symbolic fact of women's participation in the elections and of the awakening of their political awareness. The symbolic victory of Salma bint Hizab al-Oteibi, who was the first woman in Saudi Arabia to win in general elections, was at the time particularly emphasized. She beat seven men in her electoral area and won a seat on the town council of Madrakah near Mecca (Saudi Arabia. Events of 2016, 2017). What is more, in February 2017 for the first time in the history of Saudi Arabia a woman, Nura al-Fayez, was appointed as a minister, which was the effect of the implementation of the project to increase the percentage of women in public administration. She was appointed as deputy minister of education. In March 2018 Tamader bin Youssef Al-Rammah became the deputy minister of labour and social development. These two appointments can be considered as a breakthrough in the sphere of political participation of women in the kingdom, since no woman had ever taken up a post in the Saudi government before. In the ranking prepared in 2017 by the World Economic Forum on the participation of women in the economic and political life in the world, Saudi Arabia came as $138^{\text {th }}$ on the list of 144 countries covered by the survey. Any actions designed to increase political participation of Saudi women, as well as even minor changes in the political mentality of the Saudi ruling elites should thus be considered as an expression of progress. However, one should bear in mind that Saudi Arabia still remains an absolute monarchy, where elections are not of great political importance (Freedom in the World Report, 2019).

Analysing Vision 2030, one cannot deny that it is rich in initiatives aimed at presenting Saudi Arabia as a modernised and open state, where there is no place for any kind of discrimination. One of such initiatives was the decision of the authorities in Riyadh to allow the first woman to hold the role of ambassador. In September 2018 Dominique Mineur representing Belgium began her diplomatic mission in Riyadh (Stone, 2017). Then, on 23 February 2019, for the first time in the history of Saudi Arabia, a foreign diplomatic mission was led by a woman. Daughter of former Saudi ambassador to the United States in the years 1983-2005 Bandar bin Sultan Al Saud - princess Reema Bint Bandar al-Saud, known for her fight against gender-based discrimination, became the ambassador of Saudi Arabia to the USA. Analysing this appointment, it is worth to note the context of the decision of the authorities in Riyadh, as numerous experts 
have underlined that the appointment of a woman as an ambassador to the USA was to provide a new impetus in the Saudi-American relationship, which entered a difficult phase after the brutal killing of an independent journalist Jamal Khashoggi in the Saudi consulate in Istanbul, contracted by Saudi Prince Muhammad Bin Salman at the beginning of October 2018 (Hubbard, 2019). A change in the position of the ambassador and replacing King Salman's son, Prince Khalid Bin Salman, with a woman, thus constituted an important attempt to repair the image of the Kingdom of Saudi Arabia both in the USA, and in the global community.

Analysing the social reforms implemented in the Kingdom of Saudi Arabia within the framework of Vision 2030, it should also be indicated that King Salman has made a number of decisions by which he formally abolished gender segregation during state ceremonies, increased the sphere of women's participation in public and cultural life, as well as undertook numerous actions designed to increase their participation in the labour market. In accordance with the new provisions of law introduced in Saudi Arabia at the beginning of August 2019, all citizens were granted the right to work. Discrimination on grounds of gender, age or disability was prohibited. Owing to this solution, women at least in theory were given an opportunity for real employment. According to The World Factbook, the unemployment among women between the age of 15 and 24 in 2016 amounted to as much as $46.3 \%$, while among men in the same age group - to 17.4\% (Saudi Arabia, 2019).

Thus, referring to the important social changes, it should be primarily emphasized that King Salman, acting within the framework of the reforms of the Vision 2030 initiative, in his decision of September 2017 granted women the right to drive a vehicle, as Saudi Arabia was the last country where women were not allowed to get a driving licence (Zdanowski, 2004: 255-257, 266). ${ }^{2}$ On 24 June 2018 the decision on lifting the ban on women driving came into force, and within a month before its implementation about 2 thousand Saudi women received the appropriate documents. The decision, however, turned out to be very controversial, which was confirmed by the negative and critical attitude of a part of Saudi society towards publishing the photos of Princess Hayfa Bint Abdullah Al Saud on the cover of "Vogue Arabia" of June 2018. On the one hand, the conservatives emphasized that the ban on driving still applies to Saudi women and the princess should not show herself wearing bold make-up, with her face uncovered, in a red convertible and to encourage in this way women to change their social roles which should be focused on the family and carried out in accordance with the rules of Islam. On the other hand, Saudi activists emphasized that the king's decision was only a façade, as the "Vogue Arabia" cover shows a woman who had never faced the problem of lack of rights, while 11 women struggling for emancipation were arrested in May 2018 and still remained in prison. Changed versions of the magazine cover soon appeared on the Internet, with a photo of the arrested activist Lujain alHathloul (Ensor, 2018) instead of the face of the Saudi princess. ${ }^{3}$ Analysing the social

${ }^{2}$ A new, widely popular social phenomenon - mixed marriages of Saudi men to non-Saudi women - started in the 1990s. Saudi authorities were so concerned with this problem that the king himself called for Saudi-Saudi marriages.

3 The case of Raif Badawi is also very interesting. Badawi is a Saudi writer, dissident and activist, as well as the creator of the website Free Saudi Liberals. First had detained on apostasy charges in 
sphere of the changes taking place in Saudi Arabia within the framework of the Vision 2030 initiative, one should note the importance of their public perception and the façade character, since even the official act of granting women a right is not equivalent to the social ability to fully exercise such a right, especially when it contradicts the radical, Wahhabi interpretation of Islam. As for the motivation, the changes do not result from endeavours to liberalise the socio-political system, but from the rational reasons of economic nature. In the case of granting women the right to drive a vehicle the reason was prosaic - too high costs of employing drivers for the Saudi men's wives.

Women have been allowed to attend concerts, matches or to go to the cinema, which was forbidden in the past. In 2015 a Saudi woman who tried to watch a match at the stadium in Jeddah was arrested. She became a symbol of strict gender-based segregation in the kingdom. Changes in this matter were only introduced by King Salman and Prince Mohammed Bin Salman within the framework of the Vision 2030 initiative. In October 2017 a decision was announced on opening the stadiums also for women. On 12 January 2018 women for the first time were given permission to watch a football match between two local teams Al-Ahli and Al-Batin at the stadium. On 23 September women entered the stadium in Riyadh for the first time in history. Special "family sections," separated by barriers from the male-only crowd, were designated for the female spectators. Stadiums have been fitted with facilities for women, such as female prayer areas, restaurants, toilets, smoking areas and parking lots. Sections for women were opened in the King Fahd stadium in the capital, as well as in the stadiums in Jeddah (in the western part of the kingdom, in Mecca province) and in Dammam (the capital of the Eastern Province) (Shaheen, 2018). It is important to note in this context that since 2000 Saudi Arabia has been a party to the Convention on the Elimination of All Forms of Discrimination Against Women, with the reservation that only the terms which are not in contradiction with Islamic law will be observed and the provisions of Art. 9.2 and Art. 29.1 of the Convention will not be binding for the kingdom (Małachowski, 2004: 80-83). However, Riyadh does not comply with all the provisions of the Convention, and the endeavours of the authorities to improve the status of women in the Saudi society are very inconsistent. Thus, the widely announced liberalisation of the law in many spheres remains only on paper, and women - in accordance with the sharia law - still need the permission of a male relative to make major life decisions (Saudi Arabia: 10 Reasons Why Women Flee, 2019).

Moving away from the policy of discrimination and implementing the policy of social opening is evident also in a number of further significant decisions which confirm the will to modernise and gradually liberalise the system and the social norms. One of them is King Salman's decision on lifting the ban on cinemas in Saudi Arabia. On 18 April 2018 the first cinema in 35 years was opened in the business district of

2008. On 17 June 2012, he was arrested on a charge of "insulting Islam through electronic channels," and the following December he was also cited for apostasy. On 30 July 2013, Saudi media reported that Badawi had been sentenced to seven years in prison and 600 lashes for founding an Internet forum that "violates Islamic values and propagates liberal thought." The court ordered the website closed. On 9 January 2015, Badawi received 50 lashes before hundreds of spectators in front of a Jeddah mosque, the first in a total of 1,000 lashes to be administered over twenty weeks. Badawi's wife Ensaf Haidar fled to Sherbrooke in Québec, Canada, with their three children. 
Riyadh and it shows also western movies. The first film shown was the blockbuster Black Panther. What is more, Aram Aron, president of AMC Entertainment Holdings, declared that he intends to build 40 new cinemas within the following five years and as many as 350 cinemas by 2030 . Within the framework of the social change occurring in the kingdom the authorities have also decided to allow women to watch films at the cinemas. What should be stressed, however, is the fact that the development of the cinema industry is not only aimed at propagation of culture and social opening, but predominantly at supporting stability on the labour market, since opening of new cinemas means 30 thousand new full-time jobs and over four times as many part-time job positions. In macroeconomic terms, it is estimated that the development of the cinema industry causes average GDP growth by USD 24 billion (Bell, 2019).

Changing the image of the closed state, the authorities of Saudi Arabia have also decided to promote tourism within the framework of the Vision 2030 initiative. An important novelty was the possibility to obtain a tourist visa to Saudi Arabia by nonMuslims and to visit the country, of course excluding the Islamic sacred sites - Mecca and Medina (Elliott, 2019). Women over 25 travelling without a male guardian (women under 25 still need to be accompanied by a man) may also apply for a tourist visa valid for 30 days. According to the new law of August 2019, Saudi women over 21 will be able to apply for a passport without permission from a man (Pudney, 2019). They will also be able to travel without a male guardian. As both Saudi minister of tourism and Prince Mohammed Bin Salman emphasized, this initiative constitutes one of the main elements of social and economic changes in the state, which are intended to have a strong impact on the change of the negative image of the ultraconservative country. The authorities in Riyadh permanently undertake initiatives to promote and develop the tourism sector, which occupies a very important position in the Vision 2030 initiative. Promoting tourism is expected to create more jobs, and there are also plans to turn 50 islands on the Red Sea into luxury resorts in the future. Project NEOM is one of the cornerstones of Saudi Arabia's ambitious Vision 2030 initiative.

Opening up to tourists is also evident in the decision to organise the Dakar Rally in 2020 in Saudi Arabia. The rally will depart on 5 January from Jeddah on the coast of the Red Sea and is scheduled to finish in Al Qiddiya on 17 January. Saudi Arabia is the $30^{\text {th }}$ country in the world but the first in Asia to host the Dakar Rally, which is one of the most famous sports events. The agreement on organising the rally in Saudi Arabia was concluded for 5 years and, as the authorities in Riyadh have emphasized, it constitutes an important element of the consequently implemented Vision 2030 initiative. It may therefore be concluded that the changes taking place in Saudi Arabia and promoting particular sectors of economy do not result (only) from the willingness to empower women, but above all from the strictly economic considerations (All the Dakar news, 2019).

Analysing the changes occurring in Saudi Arabia in the social sphere, it should be noted that they meet with considerable resistance from Saudi religious authorities and conservative groups. Despite the opposition of religious authorities, but also of the conservative part of the Saudi society, the authorities in Riyadh continue to take the view that area of modernisation should be expanded and should apply also to the issue of women empowerment, which can be confirmed by King Salman's statement given 
in December 2017: "there is no place between us for an extremist who sees moderation as degeneration" (Saudi Arabia. CRS Informing the legislative debate since 1914, 2018). Thus, the most difficult challenge for the authorities in Riyadh, and primarily for the Crown Prince Mohammed Bin Salman, at the end of the second decade of the $21^{\text {st }}$ century is to maintain a balance between conservatives and supporters of the reforms. This is an action which shall mean that the modernised Saudi Arabia in substance will still remain conservative.

\section{SAUDI-ISRAELI COOPERATION AS A NOVELTY IN RIYADH'S FOREIGN POLICY}

Analysing the reforms undertaken by the authorities in Riyadh, at least one dimension of the Saudi foreign policy should be particularly noted - the attitude towards Israel, which especially in the last years of the second decade of the $21^{\text {st }}$ century has undergone a significant modification.

The change in the Saudis' position with respect to the issue of relations with Israel has been undoubtedly affected by the American-Saudi allied relations, which in the period of Donald Trump's administration have become even stronger. It does not mean, however, that in the previous years there were no signals indicating the willingness to establish closer relations between Israel and Saudi Arabia. First, the public attention was drawn to the meeting of the Israeli prime minister Ehud Olmert with the secretary general of the Saudi National Security Council and the former Saudi ambassador to the United States, Prince Bandar bin Sultan, in September 2006. Then, an Israeli paper "Yedioth Ahronoth" informed that the leaders met in Amman to discuss the increased instability in the Middle East. Arab officials, however, denied that such a meeting took place and Israeli officials refused to confirm this fact.

In the second decade of the $21^{\text {st }}$ century the position of the authorities of Saudi Arabia, despite the lack of diplomatic recognition of Israel by the Saudis, was consistent with the position of Israeli authorities in at least two cases. The first one is the case of Iran as the common enemy and rival in the competition for influence in the Middle East, which was first expressed by the negative reception of the so-called nuclear deal, the Joint Comprehensive Plan of Action (JCPA) of 2015 by both the countries, and then by the positive reception of the unilateral termination of this agreement by the American party at the beginning of May 2018 (Marcus, 2018). The other one is the case of Syria, as Riyadh, similarly to Israel, saw an opportunity for a favourable change in the geopolitical power structure in the region, if Bashar al-Assad's regime in Syria, which has been an ally of Iran (and Russia) for years, was overthrown. Dislodging Syria from the Iranian orbit was perceived, both in Saudi Arabia and in Israel (but also in the USA), as weakening of the influence of Tehran in Lebanon and in the territory of Palestinian National Authority (Hyra, 2016: 52). What is more, in the second decade of the $21^{\text {st }}$ century there appeared many other signals confirming the existence of unofficial relations between Saudi Arabia and Israel (Benn, 2007). In May 2016 Saudi Prince Turki al-Faisal met the retired Israeli general Yaakov Amidror in the Washington Institute for Near East Policy, and another retired Israeli general Shimon Shapira 
stated in the context of contacts with Saudi Arabia: "We discovered we have the same problems and same challenges and some of the same answers" (Totten, 2019). Then, a survey carried out in 2016 by the IDC Institute for Policy and Strategy has shown that only $18 \%$ of the Saudis perceived Israel as their main enemy, while $22 \%$ expressed the opinion that the so-called Islamic State is the major threat (Cockburn, 2015: 1-5) and as many as $53 \%$ thought that the greatest threat is posed by Iran. Such results were the evidence of a change in the perception of the region and the major threats not only by the authorities w Riyadh, but also by the Saudis themselves. In November 2017 one of the members of the Israeli cabinet admitted in public that there are contacts with Saudi Arabia (Walsh, 2017).

In March 2018, for the first time in 70 years, Saudi Arabia opened its airspace for a passenger airplane which was flying to Israel. Israeli Minister of Transportation, Israel Katz, said when the Air India plane landed at the Ben Gurion Airport in Tel Aviv: "This is a historic evening. The Israeli skies are connecting with the Saudi Arabian skies in one direct flight $[\ldots]$ We are celebrating the strengthening relations with India and the first civilian connection with Saudi Arabia and the Gulf states" (Holmes, 2018). He referred also to the flight over the territory of Oman, which does not have official diplomatic relations with Israel. Katz's words are another proof of the progressive Saudi-Israeli closeness. Of great importance in this context was also the position of Saudi Prince Muhammad ibn Salman, who in the interview for the American magazine "The Atlantic" admitted that the Israelis have the right to live in their own peaceful nation and that a peace agreement is necessary for the Middle East to ensure the stability for everyone to have normal relations. This statement engaged the interest of all the parties participating in the resolution of the Middle East conflict and having influence on the power structure existing in this part of the world, since so far no so high-ranking representative of Saudi Arabia had recognised Israel's right to exist (Bachner, 2018). Furthermore, King of Saudi Arabia, Salman emphasized in the telephone conversation with the American president Donald Trump, that Palestinian people has the right to an independent state with Jerusalem as its capital and a peace process should be continued within the framework of international relations (Kavaler, 2018). According to "The New York Times," in December 2018 Saudi Prince Mohammed Bin Salman supported the Middle East Peace Plan devised by president Trump's son-in-law Jared Kushner, as a form of redress for the assassination of Jamal Khashoggi. It should be noted that president Donald Trump and prime minister Benjamin Netanjahu, despite the clearly expressed general disapproval, publicly supported bin Salman among the global criticism of his alleged involvement in the killing of the journalist Jamal Khashoggi.

What seems to be of greatest significance in the context of Saudi Arabia's closeness to Israel is the fact that both political cooperation of these two entities, which is ever-increasing in the second decade of the $21^{\text {st }}$ century, and the positive change in the attitude of the Saudi and Israeli societies towards each other, perfectly fit into the pursuit of interests and goals of the policy of the United States towards the Middle East. Saudi Arabia becomes thus another (potential) Arab ally of Israel in the Middle East, after Egypt and Jordan. In turn, the American-Israeli allied relations and AmericanSaudi relations constitute the foundations for the Israeli-Saudi closeness, and the USA plays the role of an informal connecting link between Saudi Arabia and Israel. The 
convergence of political interests of these three entities, focusing mainly on weakening (and even annihilation) of the common enemy, which is the Islamic Republic of Iran, makes the historical events and the ethno-religious animosities lose importance. The Saudi-Israeli cooperation thus constitutes an important novelty in Riyadh's foreign policy and perfectly fit into the implementation of the scenario of strengthening the position of the kingdom and assuming the role of a hegemon in the Middle East, which has been effectively achieved by the authorities of Saudi Arabia within the framework of the Vision 2030 initiative.

$* * *$

Saudi Arabia is undoubtedly one of the most important players on the Middle East scene, and also on the global scene. This is a state which not only exhibits the attributes of a regional power (of economic, political, cultural and religious character), but also effectively uses the soft and hard power tools to strengthen and even expand its power. Finally, this is a state which due to the allied relations with the United States plays the role of the American client state in the Middle East and whose interests and goals in its foreign policy towards the region are convergent with the American ones. Saudi Arabia is a state whose leaders (particularly the heir to the throne Mohammed bin Salman) realise the need for reforms, especially economic ones, to maintain this state of power. Vision 2030 constitutes the most important instrument which at the end of the second decade of the $21^{\text {st }}$ century is to help effectively maintain the role of the Kingdom of Saudi Arabia as a regional power.

Summing up, it can be stated that the above hypothesis has been verified positively. Saudi Arabia at the end of the second decade of the $21^{\text {st }}$ century is a regional power and an absolute monarchy undergoing reforms, which intends to build a new, positive and friendly image of the kingdom in the international community through introduction of reforms in the economic, political and social spheres. The reforms undertaken within the framework of the most important and even revolutionary program, Vision 2030, however, actually take place only in the economic sphere, as it does not contradict the sharia law and the principles of Wahhabism. Changes occurring in other spheres constitute only an implication of the economic transformation and result from the strictly economic considerations.

However, in the political and social spheres - especially as regards granting further privileges and rights to Saudi women - although they are extremely important and even of breakthrough character and the very fact of their existence should be recognised, in reality they are only a façade and their implementation meets resistance not only from a part of political elites and radical clergy but also from the society itself, which is not mentally prepared for such changes. The opponents of the reforms mainly raise the argument that the reforms contradict the principles of the Quran, or rather its radical (Wahhabi) interpretation, as it should be underlined that Islam does not prohibit women from participating in public life, and the restrictions and limitations which have been functioning in Saudi Arabia for centuries result from the long-established tradition and cultural barriers, and not from the teachings of Quran. 
Therefore, it is important to emphasize this duality of the socio-political situation and the dilemmas which concern Saudi Arabia at the end of the second decade of the $21^{\text {st }}$ century. The Kingdom of Saudi Arabia is a feudal monarchy undergoing a highly important process of transformation towards the enlightened monarchy. Some of the Saudi elites demand reforms and support the Vision 2030 initiative, in which they perceive an opportunity to enhance the quality of life and to strengthen the position of the state in the role of the regional hegemon. Nevertheless, a significant part of the elites are either against the reform or unaware of the need for the reforms and of their importance. The problem is that reforms are seen as a threat to the socio-political status quo, as Saudi Arabia is a state which since the moment of its proclamation has been based on Wahhabism, and the radical clergy - ultraconservative imams - in a way legitimate the ruling of the House of Saud.

\section{REFERENCES}

All the Dakar news (2019), https://www.dakar.com/en (27.07.2019).

Al-Rushaid W. (2010), Strengthening of National Capacities for National Development Strategies and Their Management: An Evaluation of UNDP's Contribution Country Study - Saudi Arabia, http://web.undp.org/evaluation/documents/thematic/cd/Saudi-Arabia.pdf (22.06.2019).

Bachner M. (2018), Saudi prince said to use Israeli-Palestinian conflict to get Kushner's support, 9 December, https://www.timesofisrael.com/saudi-prince-said-to-use-israeli-palestinianconflict-to-get-kushners-support/ (20.03.2019).

Bell J. (2019), A magical first year at the movies as Saudi cinemas herald big screen revival, April 18, https://www.arabnews.com/node/1484156/saudi-arabia (22.05.2019).

Benn A. (2007), Israel's Liaison to Its Neighbours: Saudi Prince Bandar, Mar 02, https://www. haaretz.com/1.4808822 (22.04.2019).

Blanchard C. M. (2011), Saudi Arabia: Background and U.S. Relations, Congressional Research Service Report, March 10, http://www.fas.org/sgp/crs/mideast/RL33533.pdf (25.06.2019).

Cockburn P. (2015), The Rise of Islamic State. ISIS and the New Sunni Revolution, London-New York.

De Bellaigue C. (2017), The Islamic Enlightenment. The modern struggle between faith and reason, London.

Elliott A. F. (2018), Visiting Saudi Arabia has never been easier - here's why you should go, 3 October, https://www.telegraph.co.uk/travel/news/saudi-arabia-new-tourist-visa-whereto-visit/ (22.03.2019).

Ensor J. (2018), Vogue Arabia under fire for 'tone deaf' front cover on Saudi Princess driving, 31 May, https://www.telegraph.co.uk/news/2018/05/31/vogue-arabia-fire-tone-deaffront-cover-saudi-princess-driving/ (22.06.2019).

Freedom in the World Report (2019), https://freedomhouse.org/report/freedom-world/2019/saudiarabia (22.07.2019).

Holmes O. (2018), Israel-bound plane flies over Saudi Arabia for first time, 23 Mar, https://www. theguardian.com/world/2018/mar/23/israel-bound-flight-crosses-saudi-arabia-airspace-firsttime (20.03.2019). 
Hubbard B. (2019), Saudi Arabia appoints princess as US ambassador, 24 February 2019, https:// www.independent.co.uk/news/world/middle-east/saudi-arabia-princess-reema-us-ambassador-mohammed-bin-salman-female-a8794181.html (25.05.2019).

Hyra M. (2016), Zaangażowanie Arabii Saudyjskiej w aktualne konflikty zbrojne na Bliskim Wschodzie - przyczyny i perspektywy, "Przegląd Geopolityczny", No. 17.

Jaffe A. M. (2019), IPO Politics and the Saudi U.S. Visit, Council on Foreign Relations, https://www. cfr.org/blog/ipo-politics-and-saudi-us-visit (22.06.2019).

Kavaler T. (2018), Israel and Saudi Arabia: A complicated affair, December 15, https://www.ynetnews.com/articles/0,7340,L-5425471,00.html (20.03.2019).

King Salman Bin Abdulaziz Al Saud (2019), Vision 2030, https://www.vision2030.gov.sa/en/node (22.06.2019).

Kaldor M. (2014), New and Old Wars. Organized Violence in a Global Era, Cambridge.

Małachowski G. (2011), System konstytucyjny Arabii Saudyjskiej, Warszawa.

Marcus J. (2018), Israel and Saudi Arabia: The relationship emerging into the open, 3 April, https:// www.bbc.com/news/world-middle-east-43632905 (25.03.2019).

Memorandum of Understanding between the Government of the United States of America and the Government of the Kingdom of Saudi Arabia Concerning Cooperation in Nuclear Energy and Other Energy Fields (2008), May 16, https://fas.org/nuke/guide/saudi/mou-2008.pdf (20.07.2019).

Nair D., Narayanan A., Martin M. (2019), Saudi Aramco to Restart Preparations for Mega IPO, https:// www.bloomberg.com/news/articles/2019-07-02/saudi-aramco-is-said-to-restart-preparations-for-mega-ipo (20.07.2019).

Prados A. B. (2006), Saudi Arabia: Current Issues and U.S. Relations, Congressional Research Service Report, February 24, http://www.fas.org/sgp/crs/mideast/IB93113.pdf (27.11.2018).

Pratt D. (2006), Terrorism and Religious Fundamentalism: Prospects for a Predictive Paradigmi, "Marburg Journal of Religion", Vol. 11, No. 1.

Pudney H. (2019), Here's what we know about Saudi Arabia's tourist visas for women, January 15, https://emirateswoman.com/heres-what-we-know-about-saudi-arabias-tourist-visas-forwomen/ (22.03.2019).

Pustelnik D., Lucic A. (2009), American Relations with Saudi Arabia: An Assessment of Shifting Policies, "National Security And The Future", No. 10.

Ruys T., Ferro L. (2016), Weathering the Storm: Legality And Legal Implications of the Saudi-Led Military Intervention in Yemen, "International \& Comparative Law Quarterly", Vol. 65, Issue 1.

Saudi Arabia (2019), The World Factbook, https://www.cia.gov/library/publications/the-worldfactbook/geos/sa.html (25.01.2019).

Saudi Arabia. CRS Informing the legislative debate since 1914 (2018), February 7, https://fas.org/ sgp/crs/ mideast/IF10822.pdf (10.05.2019).

Saudi Arabia. Events of 2016 (2017), Human Rights Watch Report, https://www.hrw.org/world-report/2017/country-chapters/saudi-arabia (23.06.2019).

Saudi Arabia: 10 Reasons Why Women Flee (2019), Human Rights Watch, https://www.hrw.org/ news/2019/01/30/saudi-arabia-10-reasons-why-women-flee (25.05.2019).

Saudi National Atomic Energy Project SNAEP (2019), https://www.kacare.gov.sa/en/snaep/Pages/ ov.aspx (21.01.2019).

Scwebel S. M. (2010), The kingdom of Saudi Arabia and Aramco arbitrate the Onassis agreement, "The Journal of World Energy Law \& Business", Vol. 3, Issue 3. 
Shaheen K. (2018), Saudi football stadium welcomes women for first time, 12 January, https://www. theguardian.com/world/2018/jan/12/saudi-football-stadiums-prepare-welcome-womenfirst-time (23.04.2019).

Stone J. (2017), Belgium becomes first country to make a woman its ambassador to Saudi Arabia, 18 December, https://www.independent.co.uk/news/uk/politics/saudi-arabia-belgium-woman-ambassador-dominique-mineur-a8116691.html (22.05.2019).

Totten J. M. (2019), The New Arab-Israeli Alliance, http://www.worldaffairsjournal.org/article/newarab\%E2\%80\%93israeli-alliance (15.02.2019).

U.S.-Saudi Relations, Council on Foreign Relations (2018), December 7, https://www.cfr.org/backgrounder/us-saudi-arabia-relations (25.06.2019).

Vision 2030 (2019), Kingdom of Saudi Arabia, https://vision2030.gov.sa/en/foreword (23.01.2019).

Walsh D. (2017), Despite Public Outcry, Egypt to Transfer Islands to Saudi Arabia, "The New York Times", June 14, https://www.nytimes.com/2017/06/14/world/middleeast/egypt-saudi-arabia-islands-sisi.html (20.03.2019).

Yateem A. A. (2014), The Predicament of Shia Fundamentalism In Bahrain, "Central European Journal of International and Security Studies", No. 3.

Zdanowski J. (2004), Arabia Saudyjska, Warszawa.

Zepp Jr. I. G. (1992), A Muslim Primer. Beginner's Guide to Islam, London.

\begin{abstract}
The research objective of this paper is an analysis of the determining factors which allow Saudi Arabia at the end of the second decade of the 21st century to hold the position of a regional power and to maintain it at least in the medium-term perspective. This paper also aims at an analysis of the potential effectiveness of the reforms which have been implemented by the authorities in Riyadh in order to build a new, modified image of the feudal monarchy - Saudi Arabia as an enlightened (but permanently absolute) monarchy undergoing reforms. The hypothesis formed in this paper is as follows: Saudi Arabia at the end of the second decade of the $21^{\text {st }}$ century is a regional power and an absolute monarchy undergoing reforms, which intends to build a new, positive and friendly image of the kingdom by way of reforms introduced in the economic, political and social spheres. The reforms, however, actually take place only at the economic level, which results from the fact that they do not undermine the foundations of the sharia law and the doctrine of Wahhabism. In the political and social spheres the reforms are just a façade. The methods used in this paper include: content analysis, systemic analysis and comparative method. The findings: the hypothesis posed above has been verified positively. Saudi Arabia at the end of the second decade of the $21^{\text {st }}$ century is a regional power and an absolute monarchy undergoing reforms, which intends to build a new, positive and friendly image of the kingdom in the international community through introduction of reforms. The reforms undertaken within the framework of the Vision 2030 initiative are revolutionary, but actually they take place only in the economic sphere. However, in the political and social spheres - especially as regards granting further privileges and rights to Saudi women - although they are extremely important and even of breakthrough character and the very fact of their existence should be recognised, in reality they are only a façade and their implementation meets resistance not only from a part of political elites and radical clergy but also from the society itself, which is not mentally prepared for such changes.
\end{abstract}

Keywords: Saudi Arabia, feudal monarchy, transformation, Vision 2030 


\section{ARABIA SAUDYJSKA JAKO MOCARSTWO REGIONALNE I REFORMUJĄCA SIE MONARCHIA ABSOLUTNA. VISION 2030 INITIATIVE - PERSPEKTYWA Z KOŃCA DRUGIEJ DEKADY XXI WIEKU}

\section{STRESZCZENIE}

Celem badawczym niniejszego artykułu jest dokonanie analizy determinant, które sprawiają, że Arabia Saudyjska u schyłku drugiej dekady XXI wieku posiada i w perspektywie co najmniej średnioterminowej utrzyma pozycję mocarstwa regionalnego. Celem jest również analiza potencjalnej efektywności reform, które wprowadzają władze w Rijadzie, na rzecz zbudowania nowego, zmodyfikowanego wizerunku feudalnej monarchii, jaką jest Arabia Saudyjska, na rzecz reformującej się i oświeconej monarchii (aczkolwiek permanentnie absolutnej). Hipoteza postawiona w niniejszym artykule, brzmi następująco: Arabia Saudyjska u schyłku drugiej dekady XXI wieku to mocarstwo regionalne i reformująca się monarchia absolutna, która poprzez wprowadzane reformy w sferach ekonomicznej, politycznej i społecznej zmierza do zbudowania nowego pozytywnego i przyjaznego wizerunku królestwa. Reformy faktycznie zachodzą jednak tylko w płaszczyźnie ekonomicznej, co wynika z faktu, iż nie godzi to w podstawy prawa szariatu i zasady wahabizmu. W płaszczyznach politycznej i społecznej, reformy mają tylko charakter fasadowy. Metody wykorzystane w artykule to analiza treści, analiza systemowa, jak również metoda komparatywna. Dokonane ustalenia: hipoteza postawiona na wstępie została pozytywnie zweryfikowana. Arabia Saudyjska u schyłku drugiej dekady XXI wieku to mocarstwo regionalne i reformująca się monarchia absolutna, która poprzez wprowadzane reformy zmierza do zbudowania nowego pozytywnego i przyjaznego wizerunku w społeczności międzynarodowej. Reformy w ramach Vision 2030 są rewolucyjne, ale faktycznie dokonują się tylko w sferze ekonomii. W płaszczyznach politycznej i społecznej - zwłaszcza w materii przyznawania Saudyjkom kolejnych przywilejów i praw - mimo iż są niezwykle istotne, a nawet przełomowe i należy docenić sam fakt ich zaistnienia, to jednak mają charakter fasadowy i jedynie wizerunkowy, a ich implementacja napotyka nie tylko na opór części elit politycznych, radykalnych duchownych, ale również saudyjskiego społeczeństwa mentalnie nieprzygotowanego do takich zmian.

Słowa kluczowe: Arabia Saudyjska, monarchia feudalna, transformacja, Vision 2030 